\title{
GANGGUAN POLA NAFAS TIDAK EFEKTIF PADA PASIEN CONGESTIVE HEART FAILURE (CHF)
}

\author{
Wilantika Ida Wardani ${ }^{1}$, Yuyun Setyorini ${ }^{2}$, Akhmad Rifai ${ }^{3}$ \\ 1,2,3, Poltekkes Kemenkes Surakarta Jurusan Keperawatan \\ Diterima : 27 Oktober 2018 , Disetujui : 4 November 2018 \\ e-mail: wikeperawatan@gmail.com
}

\begin{abstract}
Background: Congestive Heart Failure (CHF) is the heart failure in pumping blood so that the blood supply containing oxygen and nutrients to the entire body tissues is inhibited and causes shortness of breath. Problems that arise that the breath pattern is not effective and can be arranged intervention one of them assess the frequency of breath depth. Acquire a real picture and experience in patients with Congestive Heart Failure $(\mathrm{CHF})$. Methods: The type of research used in the preparation of scientific papers is the type of descriptive research and case study design with the approach of nursing care. The number of patients who became the study respondents amounted to two people. Result: Based on observation result, it is concluded that with the same nursing diagnosis and done the same implementation there is difference of result and response between group of intervention with control group. Suggestion. Suggestions put forward in this study is the need to pay attention to the accuracy of the assessment to determine the priority problems that occur in patients and the principle of ONEC (Observation, Nursing Treatment, Education, Collaboration) on the intervention.
\end{abstract}

Keywords. Congestive Heart Failure (CHF), Ineffective Breathing Patterns, Nursing Care

\section{PENDAHULUAN}

Pada zaman sekarang banyak penyakit yang disebabkan oleh pola makan yang tidak baik maupun karena aktivitas yang kurang. Salah satunya Congestive Heart Failure (CHF) atau sering dikenal sebagai gagal jantung yang dapat terjadi di negara maju maupun negara berkembang termasuk di Indonesia. Gagal jantung adalah sindrom yang ditandai dengan sesak napas, dispnea saat aktifitas fisik, dispnea nokturnal paroksimal, ortopnea, dan edema perifer atau edema paru (Morton, 2011).

Oksigenasi merupakan kebutuhan dasar manusia yang paling mendasar yang digunakan untuk kelangsungan metabolisme sel tubuh, mempertahankan hidup dan aktivitas berbagai organ dan sel tubuh (Andarmoyo, 2012). Terapi oksigen adalah pemberian oksigen pada konsentrasi yang lebih tinggi dari udara bebas untuk mencegah terjadinya hipoksemia dan hipoksia yang akan mengakibatkan kematian sel (Patria \& Fairuz, 2012). Pemberian oksigen pada pasien dapat dilakukan melalui : nasal kanul, masker (simple face mask, rebreathing mask dan non rebreathing mask).

1. Asuhan Keperawatan pada masalah yang diambil melalui Pengkajian Primer melalui Airway menurut Sudiharto \& Sartono (2011), prioritas penilaian airway (jalan napas), yaitu 
kelancaran jalan napas, Breathing menurut Sudiharto \& Sartono (2011), mengungkapkan pertukaran oksigen dan karbondioksida bisa terjadi bila udara bisa masuk dan keluar jalan napas tanpa hambatan, tidak ada cairan atau darah di dalam paru, tidak ada infeksi di dalam paru, tidak ada tumor di dalam paru atau jaringan parut serta dinding torak dan diafragma dalam keadaan normal, Circulation menurut Sudiharto \& Sartono (2011), circulation adalah pengkajian yang dilakukan pada tingkat kesadaran, warna kulit, nadi, tekanan darah dan kontrol perdarahan. Pengkajian Sekunder dengan menggunakan S: Sign and symptom, tanda gejala yang dialami, A: Allergy, adakah riwayat atau tanda-tanda alergi, M: Medication, riwayat penggunaan obat atau pengobatan yang sedang dialami, P: Past medical history, riwayat medis sebelumnya, E: Event, apa yang sedang dilakukan tadi, $\mathrm{L}$ : Last meal, makan terakhir (Panacea, 2013).

2. Pengkajian Umum

a. Biodata pasien (nama, umur, jenis kelamin, pekerjaan, pendidikan)

b. Keluhan utama yang biasa muncul pada klien gangguan kebutuhan oksigenasi antara lain; batuk, peningkatan produksi sputum, dispnea, hemoptisis, mengi, dan chest pain (Andarmoyo, 2012).

c. Riwayat Kesehatan Masa Lalu

d. Riwayat Kesehatan Keluarga perlu di cari riwayat keluarga yang memberikan predisposisi keluhan seperti adanya riwayat sesak napas, batuk lama, batuk darah dari generasi terdahulu. e. Riwayat Pekerjaan dan Kebiasaan seperti pola hidup, misalnya minum alkohol atau obat tertentu, merokok dan situasi kerja.

f. Pengkajian Psikososial misalnya persepsi klien terhadap masalah atau penyakitnya, kebiasaan-kebiasaan klien dan keluarganya.

g. Pemeriksaan fisik

a) Inspeksi : ada tidaknya sekret, perdarahan, bengkak, frekuensi pernapasan.

b) Palpasi : nyeri tekan

c) Perkusi : pengkajian ini bertujuan untuk menilai normal atau tidaknya suara paru suara perkusi normal adalah suara perkusi sonor, yang bunyinya seperti suara "dug-dug".

d) Auskultasi : Potter \& Perry (2010), mengungkapkan auskultasi membantu mengidentifikasi bunyi jantung serta paru yang normal dan abnormal

3. Diagnosa

a. Bersihan jalan napas tidak efektif

b. Pola napas tidak efektif

c. Gangguan pertukaran gas

4. Perencanaan

Menurut Andarmoyo (2012), perencanaan dari ketiga diagnosa tersebut yaitu :

a. Bersihan jalan napas tidak efektif

b. Tujuan : Mempertahankan jalan napas agar efektif

c. Kriteria hasil :

a) Tidak terdapat suara napas abnormal

b) Saturasi dalam batas normal (95-100\%)

c) Frekuensi dalam batas normal (16-20 x per menit)

d) Tidak terdapat dispnea dan sianosis

Rencana :

a) Kaji bunyi napas, kecepatan, irama, dan kedalaman. 
b) Rasional : penurunan bunyi napas indikasi atelaksis, ronki indikasi akumulasi sekret atau ketidakmampuan membersihkan jalan napas sehingga otot aksesori digunakan dan kerja pernapasan meningkat.

c) Catat kemampuan untuk mengeluarkan sekret atau batuk efektif, catat karakter, jumlah sputum, adanya hemoptisis.

d) Rasional : pengeluaran sulit bila sekret tebal, sputum berdarah akibat kerusakan paru atau luka bronkhial yang memerlukan evaluasi/intervensi lanjut.

e) Berikan posisi semi atau fowler.

f) Rasional : meningkankan ekspansi paru dan memudahkan pernapasan.

g) Bantu atau ajarkan batuk efektif dan latihan napas dalam.

h) Rasional : ventilasi maksimal membuka area atelaksis dan peningkatan gerakan sekret agar mudah dikeluarkan.

i) Lakukan fisioterapi dada (postural drainage, clapping, perkusi, dan vibrasi)

j) Rasional : meminimalkan dan mencegah sumbatan/obstruksi saluran pernapasan.

k) Bersihkan mulut dari sekret dan suction bila perlu.

1) Rasional : mencegah obstruksi/aspirasi, suction dilakukan bila pasien tidak mampu mengeluarkan sekret.

m)Berikan obat : agen mukolitik, bronkodilator, kortikosteroid sesuai indikasi.

Rasional : menurunkan kekentalan sekret, lingkaran ukuran lumen trakeabronkial berguna jika terjadi hipoksia pada kavitas yang luas. Pola napas tidak efektif.
Tujuan: mempertahankan pola napas kembali efektif dengan Kriteria hasil :

a) Tidak terdapat dispnea

b) Frekuensi napas normal (16-20 x per menit)

Rencana :

a) Kaji frekuensi kedalaman pernapasan dan ekspansi dada.

b) Rasional : kecepatan biasanya mencapai kedalam pernapasan bervariasi tergantung derajat gagal napas. Ekspansi dada terbatas yang berhubungan dengan atelaksis dan atau nyeri dada.

c) Auskultasi bunyi napas dan catat adanya bunyi napas tambahan.

d) Rasional : ronkhi dan wheezing menyertai obstruksi jalan napas/kegagalan pernapasan.

e) Tinggikan kepala dan bantu dan mengubah posisi fowler atau semi fowler.

f) Rasional : duduk tinggi memungkinkan ekspansi paru dan mempermudah pernapasan.

g) Ajarkan latihan napas dalam.

h) Rasional : meningkatkan kemampuan otot-otot pernapasan.

i) Berikan oksigen tambahan, misalnya : nebulizer, pemberian $\mathrm{O}_{2}$.

j) Rasional : memaksimalkan bernapas dan menurunkan kerja napas, memberikan kelembaban pada membrane mukosa, dan membantu pengenceran sekret. Gangguan pertukaran gas dengan tujuan: mempertahankan pertukaran gas dan Kriteria hasil :
a) Tidak terdapat sianosis dan dispnea
b) Ventilasi adekuat
c) AGD dalam rentang normal

Rencana :

a) Kaji dispnea, takipnea, bunyi pernapasan abnormal, peningkatan 
upaya respirasi, keterbatasan ekspansi dan kelemahan.

b) Rasional : pada beberapa penyakit saluran pernapasan (misalnya : tuberkulosis paru) dapat menyebabkan luasnya jangkauan dalam paru-paru yang berasal dari bronkopneumonia yang meluas menjadi inflamasi, nekrosis, efusi pleura, dan meluasnya fibrosis dengan gejala-gejala respirasi distress.

c) Monitor gas darah.

d) Rasional : menurunnya saturasi oksigen $\left(\mathrm{PaO}_{2}\right)$ atau meningkatnya $\mathrm{PCO}_{2}$ menunjukkan perlunya penanganan yang lebih adekuat atau perubahan terapi.

e) Awasi tanda vital dan status jantung.

f) Rasional : perubahan tekanan darah menunjukan efek hipoksia sistemik pada fungsi jantung.

g) Awasi dan pantau tingkat kesadaran/status mental.

h) Rasional : penurunan kesadaran merupakan manifestasi umum hipoksia.

i) Tinggikan kepala tempat tidur dan bantu untuk memilih posisi yang mudah untuk bernapas (misalnya : fowler atau semi fowler).

j) Rasional : suplai oksigen dapat diperbaiki dengan posisi duduk tinggi dan latihan napas untuk menurunkan kolaps jalan napas, tindakan ini juga bisa meningkatkan ekspansi paru secara maksimal.

k) Anjurkan untuk bedrest, batasi dan bantu aktivitas sesuai kebutuhan.

1) Rasional : mengurangi konsumsi oksigen pada periode aspirasi.

m)Dorong untuk pengeluaran sputum/penghisapan bila ada indikasi. n) Rasional : sputum mengganggu proses pertukaran gas serta penghisapan dilakukan bila batuk tidak efektif.

o) Berikan oksigenasi tambahan sesuai indikasi dan pertahankan ventilasi mekanik dan bantu intubasi.

Rasional : dapat memperbaiki atau mencegah terjadinya hipoksia dan kegagalan napas serta tindakan untuk penyelamatan hidup.

5. Evaluasi

Evaluasi masalah kebutuhan oksigen secara umum dapat dinilai dari adanya kemampuan untuk (Andarmoyo, 2012) :

a. Mempertahankan jalan napas secara efektif ditunjukan dengan kemampuan untuk bernapas, jalan napas bersih, tidak ada sumbatan, frekuensi, irama, dan kedalaman napas normal, serta tidak ditemukan tanda hipoksia.

b. Mempertahankan pola napas secara efektif ditunjukan dengan adanya kemampuan untuk bernapas, frekuensi, irama, dan kedalaman napas normal, tidak ditemukan tanda hipoksia, serta kemampuan paru berkembang dengan baik.

c. Mempertahankan pertukaran gas secara efektif ditunjukan dengan adanya kemampuan untuk bernapas, jalan napas bersih, tidak ditemukan dispnea pada usaha napas, inspirasi dan ekspirasi dalam batas normal, serta saturasi dan $\mathrm{PCO}_{2}$ dalam keadaan normal.

Congestive Heart Failure (CHF)
adalah keadaan patofisiologis yaitu
jantung tidak stabil untuk menghasilkan
curah jantung yang adekuat sehingga
perfusi jaringan tidak adekuat dan
meningkatkan tekanan diastolik pada
ventrikel kiri, sehingga tekanan kapiler
paru meningkat (Hudak \& Gallo, 2012).


1. Klasifikasi

Menurut New York Heart Association (NYHA) dalam Muttaqin (2009), klasifikasi gagal jantung dibagi manjadi 4 yaitu :

Tabel 1. Klasifikasi Gagal Jantung

Menurut NYHA

\begin{tabular}{|c|c|c|}
\hline Kelas & Definisi & Istilah \\
\hline I & $\begin{array}{lrr}\text { Klien } & \text { dengan } & \text { kelainan } \\
\text { jantung } & \text { tetapi } & \text { tanpa } \\
\text { pembatasan aktivitas fisik }\end{array}$ & $\begin{array}{l}\text { Disfungsi } \\
\text { ventrikel kiri yang } \\
\text { asimtomatik }\end{array}$ \\
\hline II & $\begin{array}{l}\text { Klien dengan kelainan } \\
\text { jantung yang menyebabkan } \\
\text { sedikit pembatasan aktivitas } \\
\text { fisik }\end{array}$ & $\begin{array}{l}\text { Gagal jantung } \\
\text { ringan }\end{array}$ \\
\hline III & $\begin{array}{l}\text { Klien dengan kelainan } \\
\text { jantung yang menyebabkan } \\
\text { banyak pembatasan aktivitas } \\
\text { fisik }\end{array}$ & $\begin{array}{l}\text { Gagal } \\
\text { sedang }\end{array}$ \\
\hline IV & $\begin{array}{l}\text { Klien dengan kelainan } \\
\text { jantung yang segala bentuk } \\
\text { aktivitas fisiknya akan } \\
\text { menyebabkan kelelahan }\end{array}$ & $\begin{array}{l}\text { Gagal } \\
\text { berat }\end{array}$ \\
\hline
\end{tabular}

Sumber : Muttaqin (2009)

2. Penatalaksanaan

Muttaqin (2009), menjelaskan sasaran penatalaksanaan dari gagal jantung kongestif adalah untuk menurunkan kerja jantung, meningkatkan curah jantung dan kontraktilitas miokard, serta untuk menurunkan retensi garam dan air.

a. Pemberian oksigen

Pemenuhan oksigen akan mengurangi kebutuhan miokardium dan membantu memenuhi kebutuhan oksigen tubuh.

b. Terapi nitrat dan vasodilator

Penggunaan nitrat, baik secara akut maupun kronis, telah didukung dalam penatalaksanaan gagal jantung. Dengan menyebabkan vasodilatasi perifer, jantung di unloaded (penurunan afterload), pada peningkatan curah jantung lanjut, penurunan pulmonary artery wedge pressure (pengukuran yang menunjukkan derajat kongesti vaskular pulmonal dan beratnya gagal ventrikel kiri), serta penurunan pada konsumsi oksigen miokard.

c. Diuretik

Selain tirah baring, pembatasan garam dan air serta diuretik, baik oral maupun parenteral, akan menurunkan preload dan kerja jantung. Diuretik memiliki efek antihipertensi dengan meningkatkan pelepasan air dan garam natrium sehingga menyebabkan penurunan volume cairan dan merendahkan tekanan darah.

d. Digitalis

Digitalis adalah obat utama untuk meningkatkan kontraktilitas. Pada kegagalan awal pada infark miokardium akut, digitalis dapat meningkatkan jumlah potensial kerusakan miokardium dengan menyebabkan kontraktilitas. Dengan demikian, kebutuhan oksigen miokardium akan meningkat.

e. Inotropik positif

Dopamin meningkatkan curah jantung melalui peningkatan kontraktilitas jantung (efek beta) dan meningkatkan tekanan darah melalui vasokontriksi (efek alfa-adregenik). Dobutamin (dobutrex) adalah suatu obat simpatomimetik dengan kerja beta 1 adregenik. Efek beta 1 adregenik termasuk meningkatkan kekuatan kontraksi miokardium (efek inotropik positif) dan meningkatkan denyut jantung (efek kronotropik positif). Dobutamin merupakan indikasi pada keadaan syok apabila ingin didapatkan perbaikan curah jantung dan kemampuan kerja jantung secara menyeluruh.

f. Sedatif

Pada keadaan gagal jantung berat, pemberian sedatif untuk mengurangi kegelisahan dapat 
diberikan. Dosis phenobarbital 15-30 $\mathrm{mg} 4 \mathrm{x}$ sehari dengan tujuan mengistirahatkan klien dan memberi relaksasi pada klien.

g. Diet

Rasional dukungan diet adalah mengatur diet sehingga kerja dan ketegangan otot jantung minimal, dan status nutrisi terpelihara sesuai dengan selera dan pola makan klien.

h. Pembatasan natrium

Pembatasan natrium digunakan untuk mencegah, mengatur, atau mengurangi edema seperti pada hipertensi atau gagal jantung. Dalam menentukan aturan, sumber natrium harus spesifik dan jumlahnya perlu diukur dalam miligram.

Sedangkan terapi menurut Kasron (2012), penatalaksanaan terapi gagal jantung yaitu :

a. First line drugs : diuretik

Tujuan : mengurangi afterload pada disfungsi sistolik dan mengurangi kongesti pulmonal pada disfungsi diastolik.

b. Second line drugs : AngiostensinConverting Enzyme Inhibitors (ACEI)

Tujuan : membantu meningkatkan COP dan menurunkan kerja jantung. Obatnya adalah digoxin, hidralazin, isobarbide dinitrat, calsium channel blocker, beta blocker.

Angka kejadian gagal jantung kongestif di RSUP dr. Soeradji Tirtonegoro Klaten di poliklinik jantung pada bulan Januari sampai Mei 2016 terdapat 5.288 kasus. Data angka kematian pasien jantung di RSUP dr. Soeradji Tirtonegoro Klaten pada bulan Januari sampai September 2016 sebanyak 85 kasus (Triarso, 2017).
Memperoleh gambaran dan pengalaman secara nyata pada pasien dengan Congestive Heart Failure (CHF).

\section{METODE PENELITIAN}

Jenis penelitian yang digunakan adalah penelitian deskriptif. Penelitian deskriptif dimaksudkan untuk mendiskripsikan secara sistematis dan akurat suatu situasi atau area populasi tertentu yang bersifat faktual. Penelitian deskriptif bertujuan untuk memaparkan peristiwa-peristiwa penting yang terjadi pada masa kini. Hasil penelitian deskriptif sering digunakan atau dilanjutkan dengan penelitian analitik (Nursalam, 2013).

Rancangan penelitian yang digunakan adalah rancangan penelitian studi kasus. Penelitian studi kasus merupakan rancangan penelitian yang mencakup pengkajian satu unit penelitian secara intensif misalnya satu klien, keluarga, kelompok, komunitas, atau institusi. Meskipun jumlah subjek cenderung sedikit, namun jumlah variabel yang diteliti sangatlah luas (Nursalam, 2013).

Jenis penelitian yang digunakan dalam penyusunan karya tulis ilmiah ini adalah jenis penelitian deskriptif dan rancangan studi kasus dengan pendekatan asuhan keperawatan yang meliputi : pengkajian, diagnosa keperawatan, intervensi keperawatan, implementasi keperawatan, dan evaluasi keperawatan.

Subjek yang akan di observasi dalam studi kasus ini adalah 2 orang dengan gangguan pola napas tidak efektif pada Congestive Heart Failure (CHF) di ruang ICCU RSUP dr. Soeradji Tirtonegoro Klaten.

Peneliti melakukan analisis data dengan membandingkan kriteria hasil tidak terdapat dispnea dan sianosis serta 
frekuensi napas normal (16-20 x per menit) antara 2 subyek studi kasus mengenai pola napas tidak efektif pada Congestive Heart Failure (CHF) dengan jurnal studi kasus ataupun sumbersumber lain (jurnal, buku, dll).

\section{HASIL PENELITIAN}

Peneliti akan mendeskripsikan asuhan keperawatan yang dilakukan pada dua pasien kelolaan dengan Congestive Heart Failure (CHF) di bangsal ICCU RSUP dr. Soeradji Tirtonegoro Klaten. Hasil penelitian ini meliputi pengkajian, diagnosa keperawatan, intervensi, implementasi dan evaluasi.

\section{Pengkajian}

a. Pengkajian pasien $\mathrm{Ny}$. T

Pengkajian dilakukan pada hari Senin tanggal 12 Maret 2018 pukul 15.00 WIB. Data diperoleh melalui observasi, autoanamnesa, alloanamnesa, catatan medis, dan data penunjang lainnya. Dari pengkajian diperoleh data berupa identitas pasien adalah Ny. T, umur 61 tahun, alamat Klaten, Jawa Tengah, agama yang dianut Islam, tanggal masuk rumah sakit 11 Maret 2018, diagnosa medis Congestive Heart Failure (CHF). Identitas penanggung jawab, bernama $\mathrm{Tn}$. M, jenis kelamin laki - laki, umur 64 tahun, pekerjaan PNS, alamat Klaten, Jawa Tengah, hubungan dengan pasien adalah suami.

Pada pengkajian di dapatkan data bahwa alasan masuk pasien dibawa ke RSUP dr. Soeradji Tirtonegoro Klaten yaitu pasien mengalami sesak napas. Pasien mengeluh sesak napas sejak 1 hari sebelum masuk rumah sakit keluarga pasien mengatakan sudah digunakan untuk istirahat namun tidak segera membaik kemudian oleh keluarga di bawa ke IGD rumah sakit RSUP dr.
Soeradji Tirtonegoro Klaten pada pukul 10.00. Kemudian pada pukul $13.00 \mathrm{WIB}$ pasien di pindah ke bangsal ICCU dengan keadaan umum lemah, kesadaran composmentis, tekanan darah 145/83 $\mathrm{mmHg}$, nadi $122 \mathrm{x} / \mathrm{menit}$, respirasi 26x/menit, suhu $36,4^{0} \mathrm{C}$, tidak terdapat sianosis, CRT <2 detik, pasien mampu batuk dan mengeluarkan sekret. Keluarga pasien mengatakan pasien pernah di rawat di rumah sakit dengan penyakit yang sama $3 \mathrm{x}$ dan di keluarga pasien terdapat penyakit keturunan diabetes mellitus dan hipertensi. Keluarga pasien mengatakan pasien sering mengeluh cemas dan sering memikirkan tentang penyakit yang dideritanya saat ini.

Pengkajian primer didapatkan bahwa airway : pasien tidak mengalami sumbatan jalan napas. Breathing : frekuensi napas 26x/menit, terjadi retraksi dada, menggunakan otot bantu pernapasan, $\mathrm{SpO}_{2} 96 \%$, serta terpasang nasal kanul 4 liter per menit. Circulation : tekanan darah $120 / 87 \mathrm{mmHg}$, nadi $98 \mathrm{x} / \mathrm{menit}$, suhu $36.2^{0} \mathrm{C}$, tidak terjadi perdarahan pada pasien, CRT <2 detik, akral hangat. Disabillity : kesadaran dari Ny. T composmentis dengan keadaan umum lemah, pupil isokor. Exposure : ekstermitas pasien tidak mengalami kelemahan, tidak mengalami kelumpuhan dan tidak terdapat luka namun di tangan kanan terpasang infus RL 20 tetes per menit.

Pengkajian sekunder meliputi SAMPEL, Sign and symtomp : pasien mengatakan sesak napas. Allergy : keluarga pasien mengatakan pasien tidak mempunyai riwayat alergi makanan ataupun obat. Medication : keluarga pasien mengatakan pasien sebulan terakhir mengkonsumsi obat untuk penyakit jantungnya. Past medical history : 
keluarga pasien mengatakan pasien pernah di rawat dengan penyakit yang sama dan masih melakukan kontrol setiap bulan. Event : keluarga pasien mengatakan sebelumnya pasien hanya tiduran namun tiba-tiba pasien mengatakan sesak napas. Last meal : keluarga pasien mengatakan pasien makan nasi dan lauk telur serta sayur dan mampu menghabiskan 1 porsi.

Pengkajian sekunder B1-B6, B1 (brain) kesadaran composmentis, keadaan lemah, GCS E4 V5 M6, pupil isokor. B2 (breathing) frekuensi napas 26x/menit, terjadi retraksi dada, menggunakan otot bantu pernapasan, $\mathrm{SpO}_{2} 96 \%$, serta terpasang nasal kanul 4 liter per menit. B3 (blood) : tekanan darah 120/87 mmHg, nadi $98 \mathrm{x} / \mathrm{menit}$, suhu $36.2^{\circ} \mathrm{C}$, tidak terjadi perdarahan pada pasien, CRT $<2$ detik, akral hangat, tidak terdapat sianosis. B4 (bladder) terpasang kateter, urine $900 \mathrm{cc} / 24$ jam, warna kuning jernih, minum $\pm 500 \mathrm{cc}$. B5 (bowel) mukosa bibir lembab, lidah bersih, peristaltik usus $14 \mathrm{x} /$ menit, tidak terpasang NGT, makan tidak mampu menghabisakan 1 porsi makan hanya 2-5 sendok. B6 (bone) turgor kulit baik, tidak terdapat luka, tidak terdapat oedema, kekuatan otot $4,4,4,4$, terpasang infus RL 20 tetes per menit di tangan kanan.

Ny. T mendapatkan terapi infus RL $500 \mathrm{cc} / 24$ jam, injeksi furosemid $20 \mathrm{mg} / 8$ jam, candesartan $1 \times 4 \mathrm{mg}$, digoxin 1x0,25 $\mathrm{mg}$, simarc $2 \times 2 \mathrm{mg}$, nitrocaf $2 \times 2,5 \mathrm{mg}$, spironolacton $1 \times 25 \mathrm{mg}$. Dengan hasil pemeriksaan laboraturium tanggal 11 Maret 2018 yang terdapat dihalaman berikutnya.
Tabel 2. Hasil laboraturium tanggal 11 Maret 2018

\begin{tabular}{|c|c|c|c|}
\hline Pemeriksaan & Hasil & Satuan & Rujukan \\
\hline \multicolumn{4}{|l|}{ HEMATOLOGI } \\
\hline APTT & $40.7 \mathrm{H}$ & detik & $23.5-36.2$ \\
\hline \multicolumn{4}{|l|}{ PTT } \\
\hline PTT & $22.4 \mathrm{H}$ & detik & $10.8-14.4$ \\
\hline RATIO (PTT) & $1.78 \mathrm{H}$ & & \\
\hline INR (PTT) & $2.09 \mathrm{H}$ & detik & \\
\hline \multicolumn{4}{|l|}{ DARAH RUTIN } \\
\hline Hemoglobin & $10.8 \mathrm{~L}$ & $\mathrm{~g} / \mathrm{dL}$ & $12.0-16.0$ \\
\hline Eritrosit & $3.90 \mathrm{~L}$ & $10^{\wedge} 6 / \mathrm{uL}$ & $4.20-5.50$ \\
\hline Lekosit & $11.6 \mathrm{H}$ & $10^{\wedge} 3 /$ ul & $4.8-10.8$ \\
\hline Trombosit & 337 & $10^{\wedge} 3 / \mathrm{ul}$ & $150-450$ \\
\hline Hematokrit & $33.5 \mathrm{~L}$ & $\%$ & $37.0-52.0$ \\
\hline $\mathrm{MCV}$ & 86.0 & $\mathrm{fL}$ & $80.0-99.0$ \\
\hline $\mathrm{MCH}$ & 27.7 & $\mathrm{fL}$ & $27-31$ \\
\hline МCHC & $32.2 \mathrm{~L}$ & $\mathrm{~g} / \mathrm{dL}$ & $33.0-37.0$ \\
\hline RDW & $18.2 \mathrm{H}$ & $\%$ & $10.0-15.0$ \\
\hline \multicolumn{4}{|l|}{ Diff count } \\
\hline Basofil & 0.43 & $\%$ & $0-1$ \\
\hline Neutrofil & $77.6 \mathrm{H}$ & $\%$ & $50-70$ \\
\hline Eosinofil & $0.40 \mathrm{~L}$ & $\%$ & $1-3$ \\
\hline Limfosit & 14.1 L & $\%$ & $20-40$ \\
\hline Monosit & 7.52 & $\%$ & $2-8$ \\
\hline MPV & 8.6 & $\mathrm{fL}$ & \\
\hline \multicolumn{4}{|l|}{ Kimia klinik } \\
\hline Ureum & 26.7 & $\mathrm{mg} / \mathrm{dL}$ & $15.0-40.0$ \\
\hline Creatinin & $0.51 \mathrm{~L}$ & $\mathrm{mg} / \mathrm{dL}$ & $0.60-0.9$ \\
\hline Bun & 12.5 & $\mathrm{mg} / \mathrm{dL}$ & $7.0-18.0$ \\
\hline \multicolumn{4}{|l|}{ Paket elektrolit } \\
\hline Natrium & $131.9 \mathrm{~L}$ & $\mathrm{mmol} / \mathrm{L}$ & 136.0 \\
\hline Kalium & 4.70 & $\mathrm{mmol} / \mathrm{L}$ & 145.0 \\
\hline \multirow[t]{3}{*}{ Chlorida } & 101.5 & $\mathrm{mmol} / \mathrm{L}$ & $3.50-5.10$ \\
\hline & & & $98.0 \quad-$ \\
\hline & & & 107.0 \\
\hline
\end{tabular}

b. Pengkajian pasien Ny. A

Pengkajian dilakukan pada hari Kamis tanggal 29 Maret 2018 pukul 19.00 WIB. Data diperoleh melalui observasi, wawancara, alloanamnesa, catatan medis, dan data penunjang lainnya. Dari pengkajian diperoleh data berupa identitas pasien adalah Ny. A, umur 67 tahun, alamat Klaten, Jawa Tengah, agama yang dianut Islam, tanggal masuk rumah sakit 29 Maret 2018, diagnosa medis Congestive Heart Failure (CHF). Identitas penanggung jawab, bernama $\mathrm{Tn}$. $\mathrm{D}$, jenis kelamin laki - laki, umur 34 tahun, pekerjaan swasta, alamat Klaten, Jawa Tengah, hubungan dengan pasien adalah anak.

Pada pengkajian di dapatkan data bahwa alasan masuk pasien dibawa ke 
RSUP dr. Soeradji Tirtonegoro Klaten pasien mengeluh sesak napas kemudian oleh keluarga dianjurkan untuk beristirahat namun tidak segera membaik kemudian oleh keluarga di bawa ke IGD rumah sakit RSUP dr. Soeradji Tirtonegoro Klaten pada pukul 10.00. Kemudian pada pukul 13.40 WIB pasien di pindah ke bangsal ICCU dengan keadaan umum lemah, kesadaran composmentis, tekanan darah 81/48 $\mathrm{mmHg}$, nadi $81 \mathrm{x} / \mathrm{menit}$, respirasi $26 \mathrm{x} /$ menit, suhu $36,6^{\circ} \mathrm{C}$, tidak terdapat sianosis, CRT <2 detik, pasien mampu batuk dan mengeluarkan sekret. Keluarga pasien mengatakan pasien pernah di rawat di rumah sakit dengan penyakit yang sama lebih dari $5 \mathrm{x}$ dan di keluarga pasien terdapat penyakit keturunan hipertensi dan jantung. Keluarga pasien mengatakan pasien sudah pasrah dengan penyakit yang dideritanya saat ini dikarenakan seringnya pasien masuk ke rumah sakit dengan penyakit yang sama.

Pengkajian primer didapatkan bahwa airway : pasien tidak mengalami sumbatan jalan napas, breathing : frekuensi napas 24x/menit, terjadi retraksi dada, menggunakan otot bantu pernapasan, $\mathrm{SpO}_{2} 97 \%$, serta terpasang nasal kanul 5 liter per menit. Circulation : tekanan darah $98 / 48 \mathrm{mmHg}$, nadi 74 $\mathrm{x} /$ menit, suhu $36.5^{\circ} \mathrm{C}$, tidak terjadi perdarahan pada pasien, CRT <2 detik, akral hangat, tidak terdapat sianosis. Disabillity : kesadaran dari Ny. A composmentis dengan keadaan umum lemah, pupil isokor. Exposure ekstermitas pasien tidak mengalami kelemahan, tidak mengalami kelumpuhan dan tidak terdapat luka namun di tangan kanan terpasang infus $\mathrm{NaCl} 20$ tetes per menit.
Pengkajian sekunder meliputi SAMPEL, Sign and symtomp : pasien mengatakan sesak napas. Allergy : keluarga pasien mengatakan pasien tidak mempunyai riwayat alergi makanan ataupun obat. Medication : Keluarga pasien mengatakan pasien sebulan terakhir mengkonsumsi obat untuk penyakit jantungnya. Past medical history : keluarga pasien mengatakan pasien pernah di rawat dengan penyakit yang sama dan masih melakukan kontrol setiap bulan. Event : keluarga pasien mengatakan sebelumnya pasien habis jalan dari warung yang jaraknya $\pm 100 \mathrm{~m}$. Last meal : keluarga pasien mengatakan pasien makan nasi, lauk, dan sayur serta pasien mampu mampu menghabiskan 1 porsi.

Pengkajian sekunder B1-B6, B1 (brain) kesadaran composmentis, keadaan lemah, GCS E4 V5 M6, pupil isokor. B2 (breathing) frekuensi napas $24 \mathrm{x} /$ menit, terjadi retraksi dada, menggunakan otot bantu pernapasan, $\mathrm{SpO}_{2} 97 \%$, serta terpasang nasal kanul 5 liter per menit. B3 (blood) : tekanan darah 98/48 mmHg, nadi $74 \mathrm{x} /$ menit, suhu $36.5^{\circ} \mathrm{C}$, tidak terjadi perdarahan pada pasien, CRT $<2$ detik, akral hangat, tidak terdapat sianosis. B4 (bladder) terpasang kateter, urine 850 cc/24 jam, warna kuning jernih, minum \pm 400 cc. B5 (bowel) mukosa bibir lembab, lidah bersih, peristaltik usus 12x/menit, tidak terpasang NGT, makan tidak mampu menghabiskan 1 porsi makan hanya $1 / 4-1 / 2$ porsi. B6 (bone) turgor kulit sedang, tidak terdapat luka, tidak terdapat oedema, kekuatan otot $4,4,4,4$, terpasang infus $\mathrm{NaCl} 20$ tpm di tangan kanan.

Ny. A mendapatkan terapi infus $\mathrm{NaCl} 20$ tetes per menit, injeksi arixtra 2,5 $\mathrm{mg} / 24$ jam, aspilet 1x80 mg, clopidogrel $1 \times 75 \mathrm{mg}$, atorvastatin $1 \times 40 \mathrm{mg}$. 
Tabel 3. Hasil laboraturium tanggal 29 Maret 2018

\begin{tabular}{|c|c|c|c|}
\hline Pemeriksaan & Hasil & Satuan & Rujukan \\
\hline \multicolumn{4}{|l|}{ HEMATOLOGI } \\
\hline \multicolumn{4}{|l|}{ PTT } \\
\hline PTT & 14.0 & detik & $10.8-14.4$ \\
\hline RATIO (PTT) & 1.11 & & \\
\hline INR (PTT) & 1.14 & detik & $23.5-36.2$ \\
\hline APTT & 29.8 & detik & \\
\hline DARAH & & & $12.0-16.0$ \\
\hline RUTIN & $11.6 \mathrm{~L}$ & g/dL & $4.20-5.50$ \\
\hline Hemoglobin & $3.74 \mathrm{~L}$ & $10^{\wedge} 6 / \mathrm{uL}$ & $4.8-10.8$ \\
\hline Eritrosit & $14.2 \mathrm{H}$ & $10^{\wedge} 3 / \mathrm{ul}$ & $150-450$ \\
\hline Lekosit & $465 H$ & $10^{\wedge} 3 / \mathrm{ul}$ & $37.0-52.0$ \\
\hline Trombosit & $35.6 \mathrm{~L}$ & $\%$ & $80.0-99.0$ \\
\hline Hematokrit & 95.1 & $\mathrm{fL}$ & $27-31$ \\
\hline $\mathrm{MCV}$ & 31.0 & $\mathrm{fL}$ & $33.0-37.0$ \\
\hline $\mathrm{MCH}$ & $32.5 \mathrm{~L}$ & g/dL & $10.0-15.0$ \\
\hline МСНС & 14.9 & $\%$ & \\
\hline RDW & & & $0-1$ \\
\hline Diff count & 0.13 & $\%$ & $50-70$ \\
\hline Basofil & $76.8 \mathrm{H}$ & $\%$ & $1-3$ \\
\hline Neutrofil & 1.54 & $\%$ & $20-40$ \\
\hline Eosinofil & $11.7 \mathrm{~L}$ & $\%$ & $2-8$ \\
\hline Limfosit & $9.90 \mathrm{H}$ & $\%$ & \\
\hline Monosit & 8.7 & $\mathrm{fL}$ & \\
\hline MPV & & & $15.0-40.0$ \\
\hline Kimia klinik & $68.5 \mathrm{H}$ & $\mathrm{mg} / \mathrm{dL}$ & $0.60-0.9$ \\
\hline Ureum & $1.68 \mathrm{H}$ & $\mathrm{mg} / \mathrm{dL}$ & $7.0-18.0$ \\
\hline Creatinin & $32.0 \mathrm{H}$ & $\mathrm{mg} / \mathrm{dL}$ & $7.0-31.0$ \\
\hline Bun & 29.8 & $\mathrm{U} / \mathrm{L}$ & $7.0-31.0$ \\
\hline AST (GOT) & 14.9 & $\mathrm{U} / \mathrm{L}$ & \\
\hline ALT (GPT) & & & $136.0-145.0$ \\
\hline Paket elektrolit & 141.9 & $\mathrm{mmol} / \mathrm{L}$ & $3.50-5.10$ \\
\hline Natrium & 4.01 & $\mathrm{mmol} / \mathrm{L}$ & $98.0-107.0$ \\
\hline Kalium & $109.2 \mathrm{H}$ & $\mathrm{mmol} / \mathrm{L}$ & \\
\hline Chlorida & & & \\
\hline
\end{tabular}

2. Analisa Data dan Diagnosa

Berdasarkan pengkajian yang dilakukan pada hari Senin tanggal 12 Maret 2018 pukul 15.00 WIB dapat ditegakkan diagnosa keperawatan pada Ny. T dengan Congestive Heart Failure (CHF) yaitu: Pola napas tidak efektif

Hasil pengkajian yang dilakukan diperoleh data fokus yang menunjang diagnosa tersebut yaitu data subjektif pasien mengatakan sesak napas. Data obyektif meliputi pasien tampak sesak napas, RR 26x/menit, $\mathrm{SpO}_{2} 96 \%$, terdapat retraksi dada, menggunakan otot bantu pernapasan, terpasang nasal kanul 4 liter permenit, CRT $<2$ detik, tidak terdapat sianosis, pasien mampu batuk dan mengeluarkan secret.

Berdasarkan pengkajian yang dilakukan pada hari Kamis tanggal 29 Maret 2018 pukul 19.00 WIB dapat ditegakkan diagnosa keperawatan pada Ny. A dengan Congestive Heart Failure (CHF) yaitu: Pola napas tidak efektif

Hasil pengkajian yang dilakukan diperoleh data fokus yang menunjang diagnosa tersebut yaitu data subjektif pasien mengatakan sesak napas. Data obyektif meliputi pasien tampak sesak napas, terdapat retraksi dada, menggunakan otot bantu pernapasan, RR 24x/menit, $\mathrm{SpO}_{2} 97 \%$ terpasang $\mathrm{O}_{2} 5$ liter per menit, CRT $<2$ detik, tidak terdapat sianosis, pasien mampu batuk dan mengeluarkan secret.

3. Intervensi

Berdasarkan diagnosa keperawatan yang ditegakkan pada hari Senin tanggal 12 Maret 2018 dan Kamis tanggal 29 Maret 2018 dapat direncanakan intervensi keperawatan pada Ny. $\mathrm{T}$ dan Ny. A dengan Congestive Heart Failure yaitu:

Tujuan yang ingin dicapai setelah asuhan keperawatan $3 \times 24$ jam, diharapkan pola napas pasien efektif dengan kriteria hasil sebagai berikut: pasien mengatakan tidak sesak napas/sesak napas berkurang, RR dalam rentang normal 16-20x/menit, tidak terdapat retraksi dada, tidak terdapat penggunaan otot bantu napas. Intervensi yang disusun yaitu kaji frekuensi kedalaman pernapasan dan ekspansi dada, auskultasi bunyi napas dan catat adanya bunyi napas tambahan, tinggikan kepala dan bantu mengubah posisi fowler atau semi fowler, ajarkan napas dalam, berikan oksigen tambahan. 
4. Implementasi

a. Implementasi Pasien Ny. T

Berdasarkan intervensi keperawatan yang telah disusun pada hari Senin tanggal 12 Maret 2018 dapat dilakukan tindakan keperawatan pada Ny. T dengan Congestive Heart Failure (CHF) yaitu:

Implementasi hari pertama pada $\mathrm{Ny}$. $\mathrm{T}$ dengan Congestive Heart Failure (CHF). Pada hari Senin tanggal 12 Maret 2018 pukul 15.00 WIB mengkaji frekuensi kedalaman pernapasan dan ekspansi dada dengan respon subyektif pasien mengatakan sesak napas, data obyektif pasien tampak sesak napas, RR 26x/menit, $\mathrm{SpO}_{2} 96 \%$, terdapat retraksi dada, terdapat penggunaan otot bantu pernapasan, terpasang nasal kanul 4 liter per menit. Lalu pada pukul 15.15 WIB meninggikan kepala dan membantu mengubah posisi semi fowler dengan data subyektif pasien mengatakan lebih enak dengan posisi seperti ini daripada posisi tidur telentang, data obyektif pasien tampak nyaman dan mampu mengatur napas. Pada pukul 15.30 WIB mengajarkan pasien latihan napas dalam dengan data subyektif pasien mengatakan susah karena dadanya terasa berat, data obyektif pasien tampak kesulitan, terdapat retraksi dada, terdapat penggunaan otot bantu pernapasan. Pukul 15.50 WIB mengauskultasi suara napas dengan data subyektif pasien mengatakan mengizinkan saat akan dilakukan auskultasi napas data obyektif suara napas vesikuler di semua lobus paru. Pukul 16.00 mengkaji atau mengawasi secara rutin warna kulit, kuku, dan perubahan yang terjadi pada membrane mukosa bibir dengan data subyektif pasien mengatakan tidak terjadi perubahan warna pada kulit dan kuku setelah masuk RS, data obyektif tidak ditemukan sianosis di kulit, kuku dan membrane mukosa, CRT <2 detik, nadi kuat, akral hangat.

Implementasi hari kedua pada $\mathrm{Ny}$. $\mathrm{T}$ dengan Congestive Heart Failure (CHF). Pada hari Selasa tanggal 13 Maret 2018 pukul 19.30 WIB mempertahankan posisi semi fowler dengan data subyektif pasien mengatakan sesak napas berkurang dari pada kemarin yang terasa berat saat bernapas, data obyektif RR 24x/menit, pasien tampak nyaman. Pukul 19.45 WIB mengauskultasi bunyi napas dengan data subyektif pasien mengatakan iya, data obyektif suara napas vesikuler di semua lobus paru. Pukul 20.00 WIB mengkaji frekuensi kedalaman pernapasan dan ekspansi dada dengan respon subyektif pasien mengatakan sesak napas berkurang, data obyektif pasien tampak tidak sesak napas, $\mathrm{RR} 24 \mathrm{x} /$ menit, $\mathrm{SpO}_{2} 95 \%$, terdapat retraksi dada, terdapat penggunaan otot bantu pernapasan, terpasang nasal kanul 4 liter per menit. Pukul 20.15 WIB mengajarkan pasien napas dalam dengan data subyektif pasien mengatakan sudah bisa sedikit-sedikit, data obyektif pasien tampak mampu melakukan napas dalam 3 siklus inspirasi dan ekspirasi, terdapat retraksi dada, terdapat penggunaan otot bantu pernapasan.

Implementasi hari ketiga pada Ny. $\mathrm{T}$ dengan Congestive Heart Failure (CHF). Pada hari Rabu tanggal 14 Maret 2018 pukul 14.00 WIB mengajarkan latihan napas dalam dengan data subyektif pasien mengatakan sudah bisa sedikit-sedikit, data obyektif pasien tampak mampu melakukan dengan baik, pasien mampu melakukan latihan selama 5 siklus inspirasi dan ekspirasi. Pukul. 14.15 mengkaji atau mengawasi secara rutin warna kulit, kuku, dan perubahan yang terjadi pada membrane mukosa bibir 
dengan data obyektif tidak terdapat sianosis di kulit, kuku dan membrane mukosa, CRT <2 detik, nadi kuat, akral hangat. Pukul 14.20 WIB mengauskultasi bunyi napas dengan data subyektif pasien mengatakan iya, data obyektif suara napas vesikuler di semua lobus paru. Pukul 14.30 WIB mengkaji frekuensi kedalaman pernapasan dan ekspansi dada dengan respon subyektif pasien mengatakan napasnya masih berat, data obyektif pasien tampak sesak napas, RR $24 \mathrm{x} /$ menit, $\mathrm{SpO}_{2} 98 \%$, terdapat retraksi dada, terdapat penggunaan otot bantu pernapasan, terpasang nasal kanul 4 liter per menit. Pukul 14.45 WIB mempertahankan posisi semi fowler data subyektif pasien mengatakan sesak napasnya dapat berkurang dengan posisi sekarang dan membuat nyaman, data obyektif pasien tampak nyaman.

b. Implementasi Ny. A

Berdasarkan intervensi keperawatan yang telah disusun pada hari Kamis tanggal 29 Maret 2018 dapat dilakukan tindakan keperawatan pada $\mathrm{Ny}$. A dengan Congestive Heart Failure (CHF) yaitu:

Implementasi hari pertama pada $\mathrm{Ny}$. A dengan Congestive Heart Failure (CHF). Pada hari Kamis tanggal 29 Maret 2018 pukul 19.15 WIB meninggikan kepala dan membantu mengubah posisi semi fowler dengan data subyektif pasien mengatakan nyaman, data obyektif pasien tampak nyaman. Lalu pada pukul 19.20 WIB mengajarkan pasien napas dalam dengan data subyektif pasien mengatakan bersedia namun pelan-pelan, data obyektif pasien tampak mengikuti arahan dengan baik dan mampu melakukan selama 3 siklus inspirasi dan ekspirasi. Pukul 19.30 WIB mengauskultasi suara napas dengan data subyektif pasien mengatakan iya, data obyektif suara napas vesikuler di semua lobus paru. Pada pukul 19.45 mengkaji atau mengawasi secara rutin warna kulit, kuku, dan perubahan yang terjadi pada membrane mukosa bibir dengan data subyektif keluarga pasien mengatakan warna kulit pasien sama dengan sebelum pasien masuk RS, data obyektif tidak ditemukan perubahan warna atau sianosis di kulit, kuku, dan membrane mukosa, CRT <2 detik, akral hangat, nadi kuat. Pukul 20.00 WIB mengkaji frekuensi kedalaman pernapasan dan ekspansi dada dengan respon subyektif pasien mengatakan sesak napas, data obyektif pasien tampak sesak napas RR : $24 \mathrm{x} /$ menit, $\mathrm{SpO}_{2} 98 \%$, terdapat retraksi dada, terdapat penggunaan otot bantu pernapasan, terpasang nasal kanul 5 liter per menit.

Implementasi hari kedua pada $\mathrm{Ny}$. A dengan Congestive Heart Failure (CHF). Pada hari Jum'at tanggal 30 Maret 2018 pukul 19.30 WIB mengajarkan latihan napas dalam dengan data subyektif pasien mengatakan sudah bisa, data obyektif pasien tampak mampu melakukan tanpa bimbingan, pasien mampu melakukan latihan selama 5 siklus inspirasi dan ekspirasi. Pukul 19.50 WIB mengauskultasi bunyi napas dengan data subyektif pasien mengatakan iya, data obyektif suara napas vesikuler di semua lobus paru. Pukul 20.00 WIB mengkaji frekuensi kedalaman pernapasan dan ekspansi dada dengan respon subyektif pasien mengatakan napasnya masih berat, data obyektif pasien tampak sesak napas, RR 24x/menit, $\mathrm{SpO}_{2} 100 \%$, terdapat retraksi dada, terdapat penggunaan otot bantu pernapasan, terpasang nasal kanul 5 liter per menit. Pukul 20.15 WIB mempertahankan posisi semi fowler data subyektif pasien mengatakan enak dengan 
posisi seperti ini, data obyektif pasien tampak nyaman.

Implementasi hari ketiga pada $\mathrm{Ny}$. A dengan Congestive Heart Failure (CHF). Pada hari Sabtu tanggal 31 Maret 2018 pukul 08.15 WIB mengkaji frekuensi kedalaman pernapasan dan ekspansi dada dengan respon subyektif pasien mengatakan sudah tidak merasa sesak napas, data obyektif pasien tampak rileks, RR 20x/menit, $\mathrm{SpO}_{2} 100 \%$, tidak terdapat retraksi dada, tidak terdapat penggunaan otot bantu napas, terpasang nasal kanul 3 liter per menit. Pukul 08.25 WIB mempertahankan posisi semi fowler data subyektif pasien mengatakan nyaman dengan posisi yang saat ini data obyektif pasien tampak nyaman. Pukul 08.30 WIB mengauskultasi bunyi napas dengan data subyektif pasien mengatakan bersedia data obyektif suara napas vesikuler di semua lobus paru. Pukul 08.45 WIB mengajarkan latihan napas dalam dengan data subyektif pasien mengatakan sudah bisa dan sering melakukannya, data obyektif pasien tampak mampu melakukan tanpa bimbingan, pasien mampu melakukan latihan selama 5 siklus inspirasi dan ekspirasi. Pukul 09.00 mengkaji atau mengawasi secara rutin warna kulit, kuku, dan perubahan yang terjadi pada membrane mukosa bibir dengan data obyektif tidak terdapat sianosis di kulit, kuku dan membrane mukosa, CRT <2 detik, akral hangat, nadi kuat.

5. Evaluasi

Evaluasi Ny. T dilakukan pada hari Rabu tanggal 14 Maret 2018 pukul 15.00 WIB didapatkan data subyektif pasien mengatakan masih sedikit sesak napas namun sudah sedikit lebih baik dibandingkan hari kemarin, data obyektif ditemukan peningkatan $\mathrm{SpO}_{2}$ dari $96 \%$ menjadi $98 \%$, penurunan respirasi dari 26x/menit menjadi $24 x /$ menit, penurunan retraksi dada dan terdapat penurunan penggunaan otot bantu napas, tidak terdapat sianosis, CRT $<2$ detik, akral hangat, hasil assesment masalah pola napas tidak efektif teratasi sebagian dan untuk planning dilanjutkan intervensinya mencakup kaji frekuensi kedalaman pernapasan dan ekspansi dada, auskultasi bunyi napas dan catat adanya bunyi napas tambahan, tinggikan kepala dan bantu mengubah posisi fowler atau semi fowler, ajarkan napas dalam, berikan oksigen tambahan.

Evaluasi Ny. A dilakukan pada hari Sabtu tanggal 31 Maret 2018 pukul 09.00 WIB didapatkan data subyektif pasien mengatakan sudah tidak sesak napas, data obyektif terjadi peningkatan $\mathrm{SpO}_{2}$ dari $98 \%$ menjadi $100 \%$, penurunan RR dari $24 x /$ menit menjadi $20 x / m e n i t$, penurunan retraksi dada, dan tidak menggunakan otot bantu napas, tidak terdapat sianosis, CRT $<2$ detik, akral hangat. Hasil assesment masalah pola napas tidak efektif teratasi dan untuk planning intervensi dihentikan dengan discharge planning anjurkan pasien untuk mengidentifikasi kegiatan yang menyebabkan sesak napas dan menguranginya, anjurkan pasien untuk kontrol rutin setelah pulang dari rumah sakit serta di monitor untuk intake dan output cairannya.

\section{PEMBAHASAN}

Mengenai persamaan dan perbedaan hasil temuan pada pasien kasus pertama dan kasus kedua yang dikelola mulai dari pengkajian, diagnosa keperawatan, intervensi keperawatan, implementasi keperawatan, evaluasi keperawatan. Pada pengkajian ditemukan perbedaan umur antara pasien Ny. T dan Ny. A adalah 6 
tahun. Dengan frekuensi, $\mathrm{SpO}_{2}$ dan terapi $\mathrm{O}_{2}$ yang berbeda untuk $\mathrm{Ny}$. T frekuensi napas 26x/menit, $\mathrm{SpO}_{2} 96 \%$, dan terapi $\mathrm{O}_{2} 4$ liter per menit. Pada Ny. A frekuensi napas 24x/menit, $\mathrm{SpO}_{2} 97 \%$, dan terapi $\mathrm{O}_{2} 5$ liter per menit. Serta pada pemeriksaan laboraturium ditemukan juga data yang berbeda. Di segi psikologis pasien $\mathrm{Ny}$. T masih dalam fase denial dan untuk pasien $\mathrm{Ny}$. A dalam fase acceptence.

Untuk diagnosa ditemukan data yang sama yaitu pola napas tidak efektif, intervensi yang disusun untuk $\mathrm{Ny}$. $\mathrm{T}$ dengan Ny. A adalah sama dengan tambahan intervensi dan dilakukan implementasi kaji atau awasi secara rutin warna kulit, kuku, dan perubahan yang terjadi pada membrane mukosa bibir untuk mengetahui oksigen yang terdapat di perifer mengalami gangguan atau tidak dengan hasil pada kedua pasien $\mathrm{Ny}$. $\mathrm{T}$ dan Ny. A tidak mengalami sianosis pada kulit, kuku dan mukosa bibir serta dilakukan implementasi yang sama sesuai dengan intervensi namun dengan respon yang berbeda. Misalnya pada pasien pertama Ny. $\mathrm{T}$ dengan RR 26x/menit dengan $\mathrm{SpO}_{2} 96 \%$ diberikan terapi $\mathrm{O}_{2} 4$ liter per menit pasien masih mengalami perubahan yang tidak begitu signifikan sedangkan pasien kedua $\mathrm{Ny}$. A dengan RR 24x/menit $\mathrm{SpO}_{2}$ 97\% mendapatkan terapi $\mathrm{O}_{2} 5$ liter per menit pasien mengalami perubahan yang signifikan.

Evaluasi keperawatan pada Ny. T dengan Ny. A dengan dilakukannya tindakan yang sama mendapatkan hasil yang berbeda, untuk Ny. T dengan data subyektif pasien mengatakan masih sedikit sesak napas namun sudah sedikit lebih baik dibandingkan hari kemarin, data obyektif ditemukan peningkatan $\mathrm{SpO}_{2}$ dari $96 \%$ menjadi $98 \%$, penurunan respirasi dari 26x/menit menjadi 24x/menit, penurunan retraksi dada, dan terdapat penurunan penggunanan otot bantu napas, tidak terdapat sianosis, CRT $<2$ detik, akral hangat, hasil assesment masalah pola napas tidak efektif teratasi sebagian dan untuk planning dilanjutkan intervensinya mencakup kaji frekuensi kedalaman pernapasan dan ekspansi dada, auskultasi bunyi napas dan catat adanya bunyi napas tambahan, tinggikan kepala dan bantu mengubah posisi fowler atau semi fowler, berikan oksigen tambahan.

Pada Ny. A didapatkan data subyektif pasien mengatakan sudah tidak sesak napas, data obyektif terjadi peningkatan $\mathrm{SpO}_{2}$ dari $97 \%$ menjadi $100 \%$, penurunan RR dari 24x/menit menjadi 20x/menit, penurunan retraksi dada, dan tidak menggunakan otot bantu napas, tidak terdapat sianosis, CRT <2 detik, akral hangat. Hasil assesment masalah pola napas tidak efektif teratasi dan untuk planning intervensi dihentikan dengan discharge planning anjurkan pasien untuk mengidentifikasi kegiatan yang menyebabkan sesak napas dan menguranginya, anjurkan pasien untuk kontrol rutin setelah pulang dari rumah sakit serta di monitor untuk intake dan output cairannya.

Data yang didapatkan sesuai dengan penelitian sebelumnya yang dilakukan oleh Novita Nirmalasari (2017), bahwa latihan pernapasan akan meningkatkan relaksasi otot, menghilangkan kecemasan, menyingkirkan pola aktivitas otot-otot pernapasan yang tidak berguna dan tidak terkoordinasi, melambatkan frekuensi pernapasan dan mengurangi kerja pernapasan. Penelitian ini didukung oleh penelitian oleh Sepdianto (2013), yang menunjukkan breathing exercise pada pasien dengan gagal jantung didapatkan 
hasil sangat efektif dalam menurunkan derajat dyspnea 2,14 poin $(\mathrm{p}=0,000)$ dan meningkatkan saturasi oksigen pada pasien gagal jantung sebesar $0,8 \%$ $(\mathrm{p}=0,000)$. Hasil penelitian yang dilakukan oleh Bosnak yang dilakukan pada pasien dengan gagal jantung juga mendukung penelitian ini. Hasil menunjukkan bahwa latihan pernapasan menurunkan dyspnea (Bosnak, 2011).

Penelitian yang dilakukan pada Ny. T dengan Ny. A memiliki kesamaan dengan penelitian sebelumnya yang dilakukan oleh Novita Nirmalasari (2017), dengan hasil kedua pasien $\mathrm{Ny}$. $\mathrm{T}$ dan $\mathrm{Ny}$. A mengalami kenaikan saturasi pada $\mathrm{Ny}$. $\mathrm{T}$ sebesar 2\% dan Ny. A sebesar 3\%. Kedua pasien Ny. T dan Ny. A juga mengalami penurunan frekuensi napas pada $\mathrm{Ny}$. $\mathrm{T}$ dari 26x/menit menjadi $24 \mathrm{x} /$ menit dan pada Ny. A dari $24 x /$ menit menjadi 20x/menit.

\section{KESIMPULAN DAN SARAN}

Berdasarkan hasil penelitian asuhan keperawatan pada pasien Congestive Heart Failure (CHF) dengan gangguan pola napas tidak efektif pada pasien kasus pertama yaitu pada $\mathrm{Ny}$. $\mathrm{T}$ dan pasien kasus kedua yaitu pada Ny. A di RSUP dr. Soeradji Tirtonegoro Klaten, peneliti dapat mengambil kesimpulan sebagai berikut:

1. Keadaan Ny. T sebelum dilakukan asuhan keperawatan yaitu mengalami sesak napas, terdapat retraksi dada, menggunakan otot bantu pernapasan, RR 26x/menit, $\mathrm{SpO}_{2}$ 96\%, dapat ditegakkan diagnosa pola napas tidak efektif kemudian dilakukan tindakan selama 3×24 jam diperoleh hasil gangguan pola napas tidak efektif teratasi sebagian.
2. Keadaan Ny. A sebelum dilakukan asuhan keperawatan yaitu mengalami sesak napas, terdapat retraksi dada, menggunakan otot bantu pernapasan, $\mathrm{RR} 24 x /$ menit, $\mathrm{SpO}_{2}$ 97\%, dapat ditegakkan diagnosa pola napas tidak efektif kemudian dilakukan tindakan selama 3x24 jam diperoleh hasil gangguan pola napas tidak efektif teratasi.

3. Setelah dilakukan tindakan keperawatan gangguan pola napas tidak efektif pada Ny. T teratasi sebagian dan pada Ny. A teratasi.

4. Terdapat perbedaan pada Ny. T dan Ny. A setelah dilakukan tindakan keperawatan dengan gangguan pola napas tidak efektif.

Berdasarkan studi kasus yang telah dilakukan pada Ny. T dan Ny. A dengan Congestive Heart Failure (CHF) di ICCU RSUP dr. Soeradji Tirtonegoro Klaten peneliti memberi saran sebagai berikut :

1. Pada saat menentukan intervensi perawat hendaknya selalu mengacu pada teori dan menggunakan prinsip ONEC (Observation, Nursing treatment, Education, Collaboration).

2. Pada saat melaksanakan tindakan keperawatan tetap menjalin hubungan dan komunikasi yang baik dengan pasien dan keluarga. Selain itu, setiap tindakan keperawatan yang akan dan telah dilakukan dibuat informed concent dan didokumentasikan untuk menghindari hal-hal yang tidak diinginkan.

3. Pada saat evaluasi, perlu dilakukan pengkajian ulang terhadap kondisi pasien baik secara subjektif maupun objektif, kemudian didukung dengan pemeriksaan fisik dan pemeriksaan penunjang agar kita mengetahui tingkat keberhasilan dari tindakan 
keperawatan yang telah dilakukan serta menentukan rencana tindakan keperawatan selanjutnya.

\section{DAFTAR RUJUKAN}

Andarmoyo, Sulistyo. (2012). Kebutuhan Dasar Manusia (Oksigenasi). Yogyakarta: Graha Ilmu.

Badan Penelitian dan Pengembangan Kesehatan. (2013). Riset Kesehatan Dasar. Jakarta: Kementerian Kesehatan Republik Indonesia.

Black, Joyce M. \& Jane Hokanson Hawks. (2009). Keperawatan Medikal Bedah. Singapura: Elsevier.

Bosnak-guclu M, Arikan H, Savci S, Inal-ince D. (2011). Effects of inspiratory muscle training in patients with heart failure. Respiratory Medicine.

Hidayat, A. Aziz Alimul. (2012). Pengantar Kebutuhan Dasar Manusia - Aplikasi Konsep dan Proses Keperawatan. Jakarta: Salemba Medika.

(2014). Metode Penelitian Keperawatan dan Teknik Analisa Data. Jakarta: Salemba Medika.

Hudak \& Gallo. (2012). Keperawatan Kritis : Pendekatan Asuhan Holistic Vol 1. Jakarta: EGC.

Kasron. (2012). Kelainan dan Penyakit Jantung: Pencegahan dan Pengobatannya. Yogyakarta: Nuha Medika.

Krisanty, Paula. (2009). Asuhan Keperawatan Gawat Darurat. Jakarta: Trans Info Medika.

Muttaqin, Arif. (2009). Buku Ajar: Asuhan Keperawatan Klien dengan Gangguan Sistem Kardiovaskular dan Hematologi. Jakarta: Salemba Medika.

Morton, Patricia Gonce. et al. (2011). Keperawatan Kritis. Jakarta: EGC.

Nirmalasari, Novita. (2017). NurseLine Journal Vol. 2 No. 2 Nopember 2017 Deep Breathing Exercise dan Active Range of Motion Efektif Menurunkan Dyspnea pada Pasien Congestive Heart Failure.

Nursalam. (2013). Metodologi Penelitian Ilmu Keperawatan. Jakarta: Salemba Medika.

Panacea, Tim Bantuan Medis. (2013). Basic Life Support: Buku Panduan, Ed 13. Jakarta: EGC.

Patria \& Fairuz. (2012). Terapi Oksigen Aplikasi Klinis. Jakarta: EGC.

Potter, Patricia A. \& Anne G. Perry. (2010). Fundamental Keperawatan. Jakarta: Salemba Medika.

Sepdianto, Tri Cahyo dan Maria Diah Ciptaning Tyas. (2013). Peningkatan Saturasi Oksigen Melalui Latihan Deep Diaphragmatic Breathing pada Pasien Gagal Jantung. Jurnal Keperawatan dan Kebidanan.

Sudiharto \& Sartono. (2011). Basic Trauma Cardiac Life Support. Jakarta: Sagung Seto.

Triarso. (2017). Gambaran Aktivitas Fisik Pasien Congestive Heart Failure (CHF) di Poliklinik Jantung RSUP dr. Soeradji Tirtonegoro Klaten. Didapat dari http://eprints.ums.ac.id/55462/3/BA B\%201.pdf.

Udjianti, Wajan Juni. (2013). Keperawatan Kardiovaskular. Jakarta: Salemba Medika.

Yancy, CW. dkk. (2013). Guideline for The Management of Heart Failure. American Heart Association. 
114 Jurnal Keperawatan Global, Volume 3, No 2, Desember 2018 hlm 58-131

Yudha, Egi Komara. (2011). Pedoman

Perawatan Kritis. Jakarta: EGC.

Yulianti, Devi \& Amelia Kimin. (2013).

Keperawatan Medikal-Bedah

Brunner \& Suddart. Jakarta: EGC. 